\title{
INTEGRATION OF GEOELECTRICAL METHODS IN THE DIAGNOSTIC OF A DIESEL CONTAMINATED SITE IN SANTA ERNESTINA (SP, BRAZIL)
}

\author{
Dimitri llich Kerbauy Veloso ${ }^{1}$, César Augusto Moreira ${ }^{2}$ and Ariane Raissa Pinheiro Côrtes ${ }^{1}$
}

\begin{abstract}
Hydrocarbons meet more than $50 \%$ of world wide demand for industries and main transportation means. Unfortunately, the use of this energetic matrix in large scale is the frequent cause of contamination of soil and groundwater, scenarios that present risks to human health and limit the use of natural resources. Geophysical methods constitute an important tool for the evaluation of these cases, as they offer relevant information in an indirect and comprehensive manner, with low relative cost, guiding remediation efforts in contaminated areas. In this work a geophysical study was performed in Electro DC Resistivity and Induced Polarization in a sandy tropical soil contaminated by a 58,000 diesel spilling a railway accident, and aimed to diagnose the contamination scenario after more than seven years from the incident. 11 lines of electrical imaging were performed with generation of resistivity and charge ability models integrated in 3D view blocks. The results indicated the punctual occurrence of shallow zones of low resistivity close to the place of contaminants infiltration, associated to the action of natural attenuation processes. The model presented zones of high chargeability associated to the probable presence of metallic minerals formed during and after the action of biodegradation processes. The results set pointed to a general scenario of an advanced stage of decontamination in the area, with effective natural attenuation processes.
\end{abstract}

Keywords: accident, hydrocarbons, natural attenuation, induced polarization, DC resistivity.

RESUMO. Os hidrocarbonetos atendem a mais de $50 \%$ da demanda mundial das indústrias e principais meios de transporte. Infelizmente, 0 uso desta matriz energética em larga escala é a causa frequente de contaminações de solos e águas subterrâneas, situações que representam risco à saúde humana e inviabilizam o uso de recursos naturais. Os métodos geofísicos constituem um importante instrumento de avaliação nestes casos, pois oferecem informações relevantes de maneira indireta e abrangente, com baixo custo relativo, e orientam ações de remediação de áreas contaminadas. Este trabalho realizou um estudo geofísico de Eletrorresistividade e Polarização Induzida em solo tropical arenoso contaminado por vazamento de 58.000l de diesel em acidente ferroviário, e buscou diagnosticar o cenário da contaminação decorridos mais de sete anos do acidente. Foram realizadas 11 linhas de imageamento elétrico com geração de modelos de resistividade e cargabilidade integrados em blocos de visualização 3D. Os resultados indicaram a ocorrência pontual de zonas rasas de baixa resistividade próximas ao local de infiltração de contaminantes, associadas à ação de processos de atenuação natural. 0 modelo apresentou zonas de elevada cargabilidade associadas à provável presença de minerais metálicos formados durante e após a ação dos processos de biodegradação. 0 conjunto dos resultados apontou para um panorama geral de avançado estágio de descontaminação da área, com atuação efetiva dos processos de atenuação natural.

Palavras-chave: acidente, hidrocarbonetos, atenuação natural, polarização induzida, eletrorresistividade.

\footnotetext{
1 Universidade Estadual Paulista - UNESP, Geoscience and Exact Science Institute, Geoscience and Environmental Science Post-graduation Program, Rio Claro Campus, 24-A Avenue, 1515, P0 Box 178 -13506-900 Rio Claro, São Paulo, Brazil. Phone: +55(19)3526-2819 - E-mails: dimitriveloso@hotmail.com; ariane.rpc@gmail.com 2 Universidade Estadual Paulista - UNESP, Geoscience and Exact Science Institute, Applied Geology Department, Rio Claro Campus, 24-A Avenue, 1515, PO Box 178 - 13506-900 Rio Claro, São Paulo, Brazil. Phone: +55(19) 3526-2819 - E-mail: moreirac@rc.unesp.br
} 


\section{INTRODUCTION}

Hydrocarbons are an important energetic source in the present world economic scenario. The Brazilian refinery park is represented by large complexes present in some units of the federation, from where the distribution of petroleum derivatives is made through large areas by means of an extended net of roads, railways and waterways, an activity with intrinsic risk for accidents.

Only in the State of São Paulo, the CETESB (Environmental Company of the State of São Paulo) registered over 9900 cases of contaminated areas since the beginning of the 1980's, majoritarily by petrol products, from which approximately $45 \%$ involved road and railway transport (CETESB, 2014).

The impact caused by such contamination directly affects the soil and groundwater, which constitute natural resources, fundamental to the maintenance of life and as part of the hydrological cycle, agricultural development, the food supply to urban centers, etc. In face of this fact, it is indispensable the diagnosis of the dimensions of the environmental impacts and the adequate monitoring of the evolution of the contaminants in the environment (CETESB, 2001).

The geophysical methods constitute an important tool for evaluation of these cases, as they offer in an indirect and comprehensive manner, with low relative cost, important information that contributes in the sense of guiding remedy actions of the contaminated area and, as a consequence, minimizing the damages caused to the environment and possible damages to human health (Sara, 2003; Knödel et al., 2007; König \& Weiss, 2009; Hernández-Soriano, 2014).

The geophysical assessment of DC resistivity consists on a classical method used in the investigation and monitoring of soils and groundwater affected by organic contaminants (Knödel et al., 2007). The frequent use of this method is legitimated by the elevated contrast presented between the electrical properties of the contaminants in the subsoil and the electrical properties in the geological medium (Sauck et al., 1998, 2000; Atekwana et al., 2000; Abdel Aal et al., 2006; Allen, 2007; Moreira \& Braga, 2009).

The Induced Polarization method, in its turn, consists in a long-standing geophysical tool in the mineral research of disseminated sulfides, but only recently has been used in environmental applications. Geophysical studies performed in the last decade in areas impacted by hydrocarbons presented contrast between contaminants and the geological environment for the method of Induced Polarization (Moreira et al., 2006; Martinho et al., 2006; Vaudelet et al., 2011).

Although the geophysical methods are efficient in the study of contaminated areas, the complexity of the geological environment is a factor that affects the interpretation of the contami- nants response. Besides, over time, the hydrocarbons go through physical-chemical transformations that occur naturally and alter their electrical properties.

This work involved a geophysical assessment by means of the $\mathrm{DC}$ resistivity and Induced Polarization methods in an area contaminated by a large diesel oil spill. The main target was understanding the geophysical response in a medium contaminated by hydrocarbons for more than seven years, only subjected to the action of natural attenuation.

\section{LOCATION AND HISTORY OF THE EVENT}

The study area is located in the rural area of the Santa Ernestina district (São Paulo State, Brazil) (Fig. 1), where the Adamantina Formation rocks of the Paraná Sedimentary Basin occur. The Adamantina Formation is formed by fine sands and, according to performed borings, the area presents a sandy soil with few lithologic variations.

The hydrogeological aspects observed in monitoring wells indicate shallow water level around $8.0 \mathrm{~m}$. The topography is homogeneous with a $2 \%$ inclination to the NE, same general direction of groundwater flow in the subsurface (CETESB, 2009). Hydraulic conductivity reaches the value of $0.23 \mathrm{~m} /$ day, which indicates a moderate to high conductivity in the area.

In July 2007, the site was contaminated by organic compounds resulting from an accident that involved the tumbling of five railway cars. The accident occurred in the railway stretch between Santa Ernestina and Taquaritinga. About 58,000 of diesel oil were spilled, where part infiltrated in the soil and part accumulated in contour lines in the surface (CETESB, 2007).

The oil spilled on the railway axis followed a superficial flow towards the NE and was later directed, by an emergency action of the responsible company, over a $150 \mathrm{~m}$ distance to the nearest contour line, as an attempt to minimize the infiltration area of the residue, as well as lateral containment barriers which were set around the accident perimeter. Subsequent measures consisted in the removal of the stagnant volume in the surface $(12,000 \mathrm{l})$ and the removal of 81.5 tons of soil and residues from the place (approximately 10,000I) (CETESB, 2007).

Part of the spilled oil volume reached the groundwater over a contaminated area of $2300 \mathrm{~m}^{2}$, in spite of the actions aiming to minimize the environmental impact at the site (CETESB, 2009).

Thus, in 2008 an investigation and monitoring work was initiated in the area, which included the soil gas surveys (SGS), sampling in the points where the highest SGS readings, installation of monitoring wells with depths up to $7 \mathrm{~m}$, probing through auger drilling, groundwater sampling and chemical analysis for 


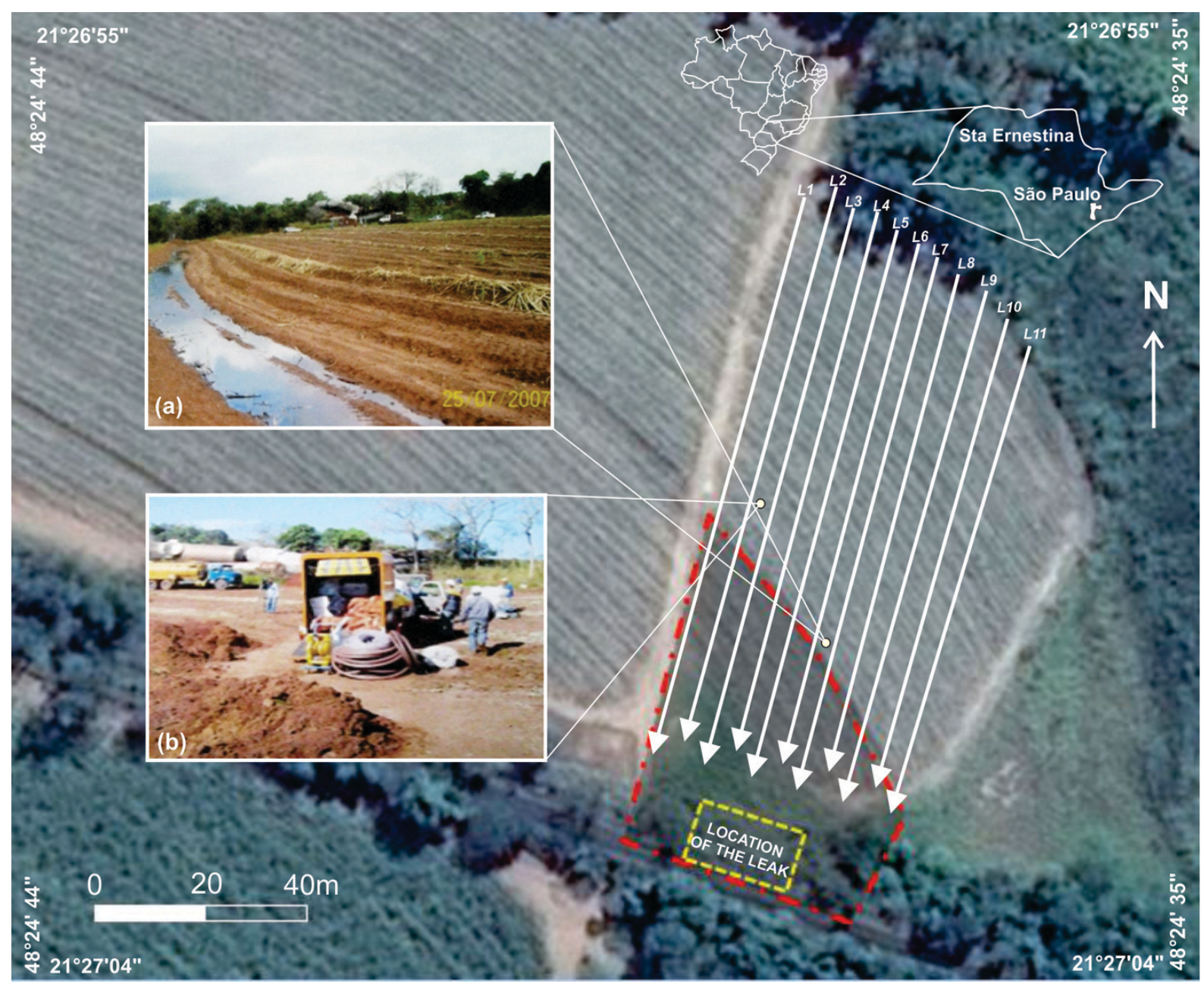

Figure 1 - Location area with history and lines of geophysical acquisition: (a) oil accumulation on the site and (b) soil removal operation.

both soil and underground samples to determine BTEX and TPH contents.

The historic series of analytical results of groundwater monitoring in the area of the accident indicated the presence of the compounds BTEX (Benzene, Toluene, Ethylbenzene and Xylenes) and TPH (Total Petroleum Hydrocarbon) (CETESB, 2007).

Later studies comprised 95 SGS points for mapping and proving the conversion of liquid hydrocarbons into methane, in a survey performed in November 2008 (Fig. 2). The monitoring of the area was extended up to September 2011, when the analyses of the contaminants in the groundwater indicated levels below the limit established by the environmental agency.

\section{NATURAL ATTENUATION}

The studies performed by means of the geochemical monitoring in the area for the first months after the accident discarded the need for active remediation actions for the site. Thus, the recovery of the study area involved exclusively a set of natural processes (physical, chemical, biochemical) that would act in the sense of reducing the contaminant concentrations (reducing the mass, volume, toxicity, mobility, etc.). To this set of processes, the name of Natural Attenuation is given, which consists in a passive remediation based in the capacity of the soil system to assimilate and transform the contaminants (EPA, 1995; EPA, 1998; Wiedemeier et al., 1999).

The use of natural attenuation as an option to remedy is accomplished by means of monitoring, based in the study of the capacity of remediation reach in a reasonable time period. The development of processes in long term must consider several criteria, relevant to the remediation aims (Declercq et al., 2012).

The transforming, retention and movement of the contaminants are controlled by physical, chemical and biological properties of the environment (EPA, 1992; Wiedemeier et al., 1999; 


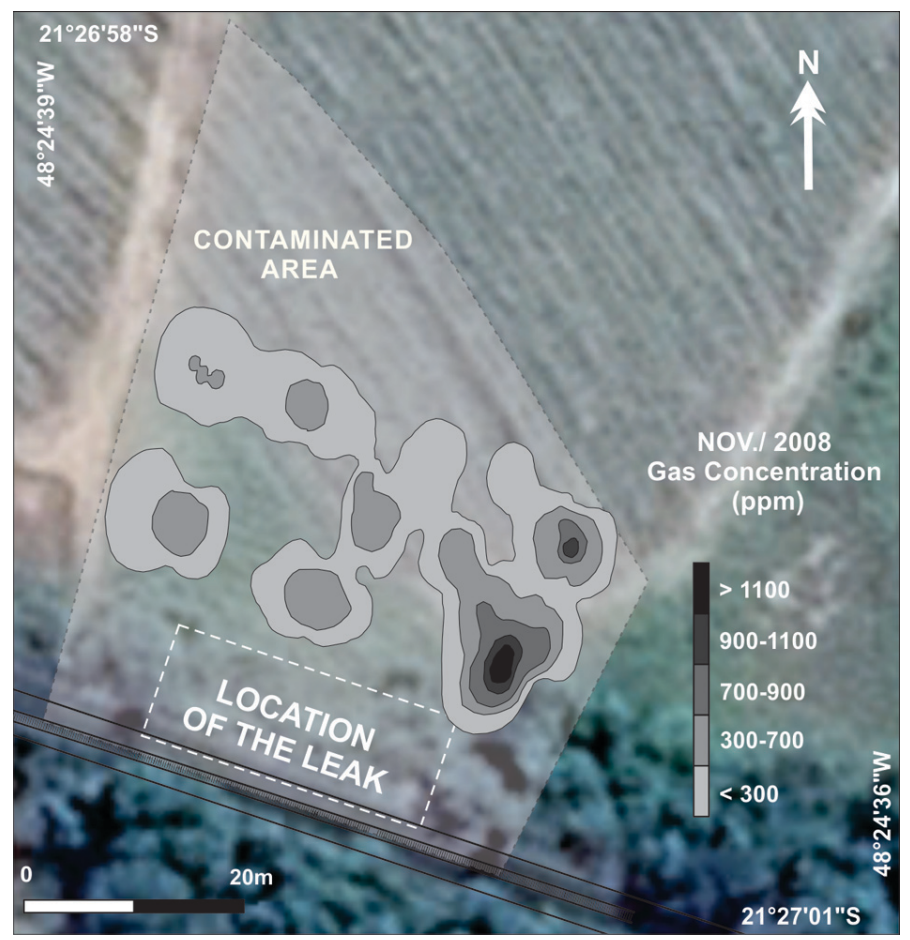

Figure 2 - Map of methane gas concentration for 2008 (CETESB, 2009).

Alvarez \& IIIman, 2006). Natural attenuation processes are well documented in sites of hydrocarbon spills, as well as BTEX, which can naturally degrade through microbial activity and generate non-toxic products such as $\mathrm{CO}_{2}$ and $\mathrm{H}_{2} \mathrm{O}$ (EPA, 1998).

The efficiency of natural attenuation processes is directly linked to physical-chemical factors such as the soil type, environment humidity, temperature, REDOX conditions, $\mathrm{pH}$, organic matter content, electron receptors for the compounds to be degraded, presence of microorganisms, availability of inorganic nutrients, soil thickness, among others (Cerniglia, 1992; EPA, 1998).

Along the processes acting in the reduction of the contaminant concentration, the contamination plume can take several forms: expanding, stable or shrinking, depending on the spatial distribution of the contamination in time (Wiedemeier et al., 1999).

The several mechanisms that contribute for the occurrence of natural attenuation can be classified as destructive and nondestructive (EPA, 1998).

The non-destructive mechanisms are responsible for the transportation of the contaminant mass in different phases of the geological environment. These processes can make facilitate microorganisms access to the contaminant mass and even increase the degradation rate of the contaminants, but they are not responsible for the reduction of the contaminants mass. The main non-destructive processes of natural attenuation are dispersion, sorption and volatilization.

The destructive mechanisms are responsible for the alteration of the chemical structure of the contaminants and involve transformation of the substances into less or non-toxic compounds. Biodegradation is the main destructive mechanism for natural attenuation and can be by aerobic or anaerobic process.

In chemical terms, biodegradation involves a set REDOX reactions, where the organic contaminants are oxidized (Lovley, 1991). The oxidation potential is the measure of the relative tendency of a solution to receive or transfer electrons.

The oxidation conditions of the media constitute one of the most important factors in the effectiveness of biodegradation, as the obtaining of energy by the microorganisms occurs from the transfer between electron donors and electron receptors. Hydrocarbons are completely degraded when used as primary electron donors for the microbial metabolism (EPA, 1995; EPA, 1999).

Dissolved oxygen is used as electron receiver during aerobic biodegradation. Anaerobic organisms use electron receivers in the following order of preference after the consumption of dissolved oxygen: nitrate, ferrous iron, sulfate and carbon dioxide. 
The anaerobic destruction of BTEX compounds is associated with accumulation of acids, solubilization, nitrate reduction, iron reduction, sulfate and methane production (EPA, 1999).

Generally, the $\mathrm{Fe}^{3+}$ cation is an abundant receptor on soils, found in sediments of most aquifers in the form of $\mathrm{Fe}(\mathrm{OH})$ and $\mathrm{Fe} 0$. Thus, reduction of $\mathrm{Fe}^{3+}$ to $\mathrm{Fe}^{2+}$ is an important an aerobic degradation mechanism (Lovley, 1991).

There is an inverse relationship between the concentration of BTEX and the oxidation potential of the geological environment. Areas with low oxidation potential coincide with areas with high BTEX contamination, low dissolved oxygen, nitrate and sulfate concentrations, and high ferrous iron and methane concentrations (EPA, 1998; Ludwig et al., 2000). Bacterial activity can be associated to an increase in oxidation conditions by means of production, something that facilitates the proliferation of microorganisms themselves (Naudet \& Revil, 2005; Vaudelet et al., 2011).

\section{DATA ACQUISITION}

The geophysical survey conducted in this study involved a single field work step in January 2015, and consisted of the application of the DC Resistivity and Induced Polarization geophysical methods through 11 parallel lines of electric imaging in the Wenner arrangement (two potential electrodes and two current electrodes with equally spaced), with $5.0 \mathrm{~m}$ spacing between lines and a $7.0 \mathrm{~m}$ electrode spacing, oriented according to the local hydraulic gradient. Electrical resistivity and chargeability measurements in 6 levels of depth were obtained.

After defining the azimuth, the process for line assembly started with the marking of the $7.0 \mathrm{~m}$ spacing between electrodes, which were fixed in small pits filled with water to reduce contact resistance. Each electrode consists of a non-polarizable porous ceramic based container filled with a copper sulfate soIution $\left(\mathrm{CuSO}_{4}\right)$, in which a copper rod is inserted for external contact. These electrodes allow current flow without interference of the electrodes polarization effects and reduces the contact resistance.

The equipment used in this work was the resistivity meter Terrameter LS, manufactured by ABEM Instrument, consisting of a single module for transmission and reception of automated signals from previous programming, with 250W, resolution of $1 \mu \mathrm{V}$ and a maximum current of 2.5A. This equipment operates through periodic transmission cycles transmission and signal reception, automatic calculation of the contact resistance and the standard deviation of the measures set. The equipment was programmed with the time of $1 \mathrm{~s}$ for current sending, minimum current of $200 \mathrm{~mA}$ and a maximum of 500mA, 2 fixed and consecutive reading-windows of $100 \mathrm{~ms}$, starting the readings after current cutting of $0.2 \mathrm{~s}$.

The inverse modeling was done using the Res2dinv software (Geotomo Software, 2003), where 2D model sections of resistivity and chargeability were generated. The Res2dinv is a $2 \mathrm{D}$ inversion software, which automatically defines a bi-dimensional model of the subsurface (in terms of distance versus approximate vertical depth) from resistivity and chargeability data, obtained from geoelectrical surveys (Griffiths \& Barker, 1993).

The 2D model sections were then exported from Res2dinv and re-imported into the Oasis Montaj Platform (Geosoft), in order to create a 3D visualization model for the charge ability. 3D visualization models generated from geophysical data are of great help in the understanding of complex geological structures and hydrological problems, like the flow of pollutants and modeling of ore deposits (Chambers et al., 2006; Aizebeokhai et al., 2011; Moreira et al., 2012). The visualization model was created by interpolating data from each section, using the Minimal Curvature algorithm.

\section{RESULTS AND DISCUSSION}

The depth maps presented and discussed in this item provide an overview of the spatial distribution of the considered parameters. By means of horizontal sections of the 3D visualization blocks for resistivity and chargeability, the depths of $1.0 \mathrm{~m}, 3.0 \mathrm{~m}$, $5.0 \mathrm{~m}$ and $7.0 \mathrm{~m}$ were analyzed (Fig. 3). The selection of depth levels for generation of the maps emphasized the unsaturated zone where the contrasts presented in the inversion models were more evident.

The northern region of the map corresponds in surface to the lower topographical area, near a drainage. The southern region of the map corresponds in the surface to the area of greatest topographic highs, near the accident location. The colors and value scales used match the scales of the 2D inversion models.

The analysis of depth maps for the modeled resistivity reveals a predominance of warm colors, i.e., high resistivity values at all analyzed levels. Homogeneity of these values, both in depth and laterally, possibly reflect natural conditions of the area.

The area where the surveys were conducted is located underneath the sandy soil of Adamantina Formation, which in mineral terms is composed essentially of quartz, mineral that presents high resistivity (Telford et al., 1990). Resistivity values of this level are consistent with dry sandy soils, as reported in Atekwana et al. (2000), where similar resistivity values $(25,000 \Omega . m)$ 

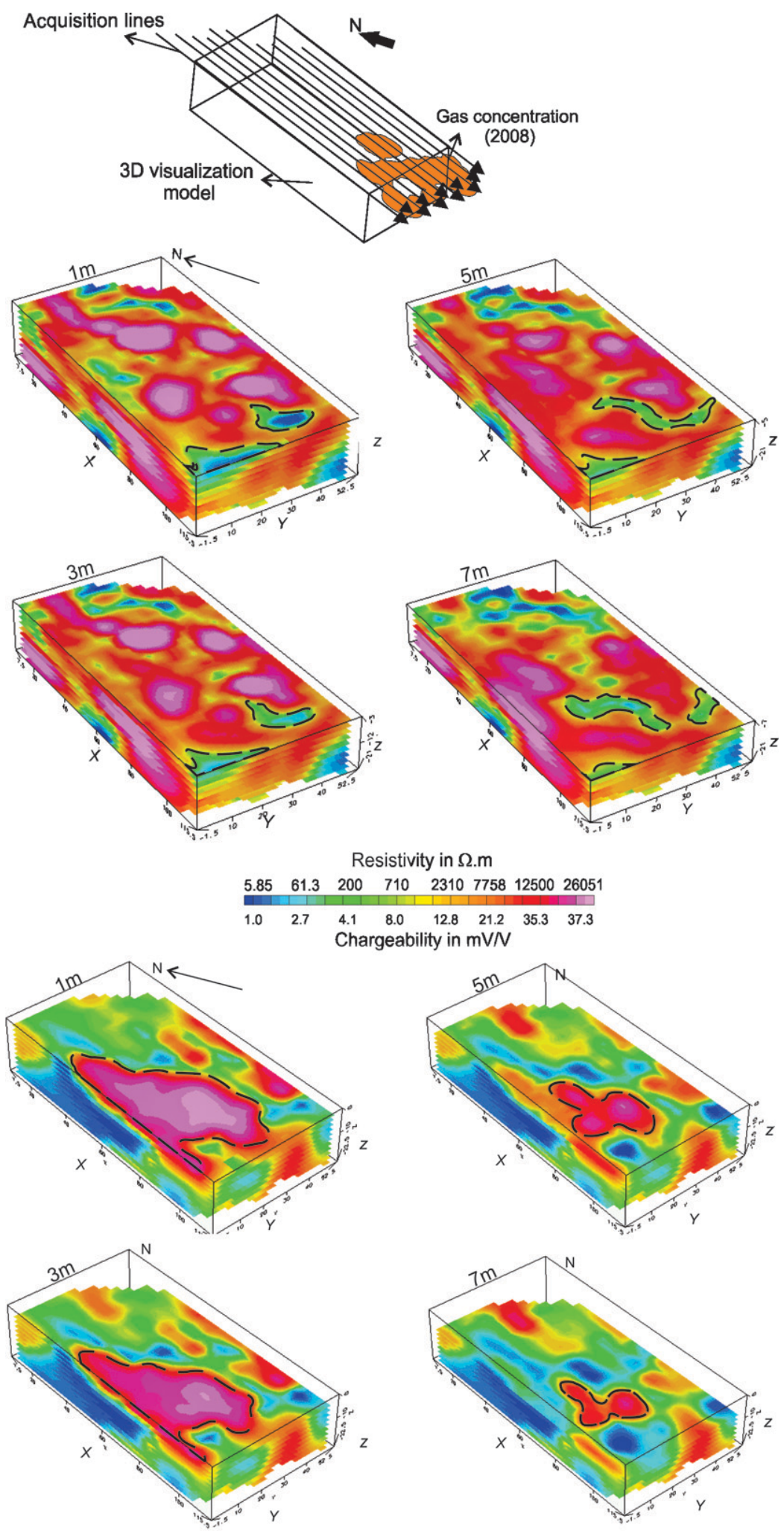

Figure 3 - Depth maps for resistivity (above) and chargeability (below). 
were related for the compartment of the unsaturated zone in a sandy soil, attributed to low local humidity (Atekwana et al., 2000; Zogala et al., 2009).

The effectiveness of the biodegradation process is favored by the physical characteristics of the environment in the study area: high porosity, permeability and hydraulic conductivity $(2.7 \times$ $10^{-4} \mathrm{~cm} / \mathrm{s}$ ), which probably contributed to greater oxygenation of the environment. This factor facilitates the occurrence of aerobic biodegradation which is the most efficient among biodegradation processes.

Despite the general pattern of high resistivity $(15,000 \Omega . m)$,

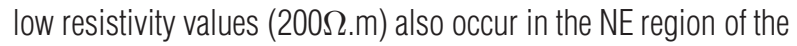
block, especially at the $7.0 \mathrm{~m}$ depth map. The proximity to the drainage (20.0 m to $30.0 \mathrm{~m}$ ), the distance from the contamination source and the increasing pattern in the occurrence area in depth indicate influence of moisture and lack of correlation with the contaminated area.

At the $1.0 \mathrm{~m}$ depth map, two zones of low resistivity were highlighted with core values around $5 \Omega \mathrm{m}$ : an anomaly to the SW and another to the SSW which, in depth, is expanded towards the center. The less resistive cores decrease in depth and reach values around $150 \Omega . \mathrm{m}$, at the $7.0 \mathrm{~m}$ depth.

These areas of low resistivity identified in the southern portion of the depth maps (enhanced in the models) are close to the source of contamination. It is the case of the area delineated in the SW portion, about $15.0 \mathrm{~m}$ away from the spillsite, which shows low resistivity and a half-moon shape in the $1.0 \mathrm{~m}$ map. As it becomes relatively more resistive $(150 \Omega \mathrm{m})$ in depth, it extends to the central region of the $3.0 \mathrm{~m}, 5.0 \mathrm{~m}$ and $7.0 \mathrm{~m}$ maps (Fig. 3).

The spatial distribution pattern of these two regions is analogous to that described in the soil gas survey maps where the higher concentrations are at SW portion and the center of the area (diesel infiltration areas). The presence of gas years after the contamination, in concentrations above 1040 ppm, indicates the occurrence of biodegradation processes.

The review of geophysical application works in hydrocarbon contamination describes a relationship between areas of low resistivity and advanced stages of natural attenuation of the compounds. The decrease in resistivity of the geological environment is related to the breaking of the hydrocarbons chains and the release of ions, by the action of oxidation, dispersion and biodegradation processes. Thus, this geophysical signature may occur in response to the biodegradation processes of the contaminants in residual phase, contained in the unsaturated zone (Sauck, 1998 and 2000; Abdel Aal et al., 2004; Atekwana \& Atekwana, 2010).
Any biological activity results in temperature increase and acceleration of oxidation-reduction reactions, which provide favorable conditions for the mineral dissolution, increase in the concentration of dissolved ions, increased porosity, mineral saturation and resulting precipitation of newly formed minerals (Juhasz \& Naidu, 2000; Sauck, 2000; Atekwana et al., 2000; Abdel Aal et al., 2004).

The infiltration, oxidation, dispersion and biodegradation processes of pollutants allowed the break of hydrocarbons chains and the release of ions. The main consequence of these processes to the geological environment is the drop in electrical resistivity. The contamination in the study area was due to a railway accident that occurred 7 years before the present survey, in which time enough has elapsed for the degradation of the products. The low resistivity shallow areas presented continuation at depth, and the increase in values could be associated to lower rates of biodegradation or the return to natural conditions.

Regarding the depth maps for chargeability, the region with high values $(36 \mathrm{mV} / \mathrm{V})$ was highlighted, corresponding to the patterns described in the $2 \mathrm{D}$ inversion models. This region is predominant in approximately $45 \%$ of the $1.0 \mathrm{~m}$ depth map area and decreases at deeper levels towards the $7.0 \mathrm{~m}$ map, in which it corresponds to approximately $13 \%$ of the area.

The high chargeability values are associated to the biodegradation processes on the contaminants because the presence of organic acids produced by biodegradation alters the initial physical-chemical conditions of the environment, causes dissolution of chemical elements and there by releases these elements as dissolved phase (Vaudelet et al., 2011).

These areas may be associated to the neoformation of metallic minerals such as Fe oxides, Fe hydroxides and sulfides (from the sulfur present in diesel oil) as a result of hydrocarbon biodegradation processes. Thus, the areas of high charge ability indicate past processes of biodegradation and suggest an advanced stage of natural attenuation.

The new conditions of $\mathrm{pH}$ and Eh arising from natural biodegradation processes favor mineral neoformation from the newly dissolved ions in order to more chemically stable structures (Moreira \& Braga, 2009; Vaudelet et al., 2011).

The frequent presence of $\mathrm{Fe}^{3+}$ in tropical soils enables the formation of metallic minerals such as oxides, hydroxides as a consequence of biodegradation processes (Lovley, 1991). The presence of these minerals provides an increase in the polarizability effect, due to the favoring of electronic polarization (Musset \& Khan, 2000; Milsom \& Eriksen, 2011), which justifies the high chargeability values. 
Besides the availability of ions and the biodegradation products, the variation of the oxidation (Eh) potential of the environment is a crucial factor for the formation of new metallic minerals. The Eh reduction facilitates the occurrence of anaerobic biodegradation processes for reducing $\mathrm{Fe}^{3+}$ (Ludwig, 2000), an important biodegradation mechanism (Lovley, 1991). The new conditions established enable neoformation of oxides, hydroxides and metallic sulfides which increase the polarization effect of the environment. Thus, there is an increased concentration of $\mathrm{Fe}^{2+}$ in solution (which is more soluble than the $\mathrm{Fe}^{3+}$ ), which in turn favors the formation of new oxides, the oxygen consumption and the resulting increase in the reducing conditions of the environment (Moreira \& Braga, 2009).

\section{CONCLUSIONS}

The geophysical survey integrated to chemical and historical data of the accident allowed to elucidate the current state of the contaminated area, initially impacted by the spillage of 58,000 of diesel 8 years ago (2007).

In general, the history of chemical analysis obtained during 4 years subsequent to the spillage, indicated a decrease in the concentrations of hydrocarbons, with values below the intervention limit in most wells during the monitoring campaign in 2011.

The integrated electrical resistivity data show a pattern of

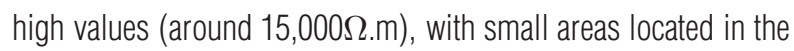

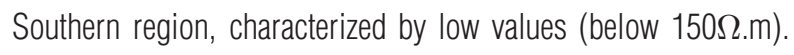
These areas of lower resistivity at depth coincide with the gas concentration maps, which indicated higher levels of contaminants in the southwest and central regions, main areas of diesel infiltration.

The integrated chargeability data revealed regions with high values (around $35 \mathrm{mV} / \mathrm{V}$ ) very comprehensive in the $1.0 \mathrm{~m}$ depth map, with a gradual reduction in area with increasing depth. This magnitude of values can be attributed to the electronic polarization phenomenon, originated in the presence of metallic minerals in the geological environment.

Thus, the high chargeability values were correlated with initially contaminated areas and indicate a record of the presence of contaminants in a past period, currently consumed due to the probable mineral neoformation from metallic ions present in soil (Fe+3 and S).

The joint application of DC Resistivity and Induced Polarization methods allowed the analysis of different processes occurring at different times: the electrical resistivity presented geophysical signatures consistent with areas in final stage of recovery, while the charge ability reflected a past record of degradation of contaminants.
In this sense, the results of this study can positively contribute to the geophysical diagnosis in similar areas in face of the effectiveness of the use of 3D visualization models, which allowed qualitative view of the current state of contamination of the area.

\section{REFERENCES}

ABDEL AAL GZ, ATEKWANA EA, SLATER LD \& ATEKWANA EA. 2004. Effects of microbial processes on electrolytic and interfacial electrical properties of unconsolidated sediments. Geophysical Research Letters, 31: L12505, doi: 101029/2004GL020030. 1-4.

ABDEL AAL GZ, SLATER LD \& ATEKWANA EA. 2006. Inducedpolarization measurements on unconsolidated sediments from a site of active hydrocarbon biodegradation. Geophysics, 71: 13-24.

AIZEBEOKHAI AP, OLAYINKA AI, SINGH VS \& UHUEGBU CC. 2011. Effectiveness of $3 \mathrm{D}$ geoelectrical resistivity imaging using parallel 2D profiles. International Journal of the Physical Sciences, 6: 5623-5647.

ALLEN JP, ATEKWANA EA, ATEKWANA EA, DURIS JW, WERKEMA DD \& ROSSBACH S. 2007. The microbial community structure in petroleumcontaminated sediments corresponds to geophysical signatures. Applied and Environmental Microbiology, 73: 2860-2870.

ALVAREZ PJJ \& ILLMAN WA. 2006. Bioremediation and natural attenuation: process fundamentals and mathematical models. WileyInterscience. Published by John Wiley \& Sons, Inc.

ATEKWANA EA \& ATEKWANA EA. 2010. Geophysical Signatures of Microbial Activity at hydrocarbon Contaminated Sites: A Review. Surveys Geophysics, 31: 247-283.

ATEKWANA EA, SAUCK WA \& WERKEMA JRDD. 2000. Investigations of geoelectrical signatures at a hydrocarbon contaminated site. Journal of Applied Geophysics, 44: 167-180.

CERNIGLIA CE. 1992. Biodegradation of polycyclic aromatic hydrocarbons. Biodegradation, 3: 331-338.

CETESB - COMPANHIA AMBIENTAL DO ESTADO DE SÃO PAULO. 2001. Manual de Gerenciamento de Áreas Contaminadas: 0 gerenciamento de áreas contaminadas. São Paulo. Available on: $\quad<$ http://www.cetesb.sp.gov.br/areas-contaminadas/manual-degerenciamento-de-areas-contaminadas/7-manual-de-gerenciamentodas-acs > . Access on: September 24, 2014.

CETESB - COMPANHIA AMBIENTAL DO ESTADO DE SÃO PAULO (Agência de Araraquara). 2007. Investigação Ambiental Confirmatória: Santa Ernestina. MARTINS DS \& NETO VA (Coord.). São Paulo, Brazil, $76 \mathrm{pp}$.

CETESB - COMPANHIA AMBIENTAL DO ESTADO DE SÃO PAULO (Agência de Araraquara). 2009. Relatório Técnico de Investigação de contaminação de água subterrânea - Santa Ernestina. CHIARINI AP. (Coord.). São Paulo, Brazil, 63 pp. 
CETESB - COMPANHIA AMBIENTAL DO ESTADO DE SÃO PAULO. 2014. Emergências Químicas - estatísticas. São Paulo: CETESB. Available on: <http://www.cetesb.sp.gov.br/gerenciamento-de-riscos/ emergencias-quimicas/145-estatisticas>. Access on: December 18, 2014.

CHAMBERS JE, KURAS 0, MELDRUM PI, OGILVY RD \& HOLLANDS J. 2006. Electrical resistivity tomography applied to geologic, hydrogeologic, and engineering investigations at a former waste-disposal site. Geophysics, 71: 231-239.

DECLERCQ I, CAPPUYNS V \& DUCLOS Y. 2012. Monitored natural attenuation (MNA) of contaminated soils: State of the art in Europe - A critical evaluation. Science of the Total Environmental, 426: 393-405.

EPA - United States Environmental Protection Agency. 1992. Estimating the potential for occurrence of DNAPL at Superfund sites. U.S. Environmental Protection Agency. 159 pp.

EPA - United States Environmental Protection Agency. 1995. Chapter IX: Natural Attenuation. How to Evaluate Alternative Cleanup Technologies for Underground Storage Tank Sites: A Guide for Corrective Action Plan Reviewers. Washington DC, EPA/510/B-95/007. 343 pp. Available on: <http://www.epa.gov>. Access on: October 13, 2014.

EPA - United States Environmental Protection Agency. 1998. Technical Protocol for Evaluating Natural Attenuation of Chlorinated Solvents in Ground Water. Washington DC, EPA/600/R-98/128. 53 pp. Available on: <http://www.epa.gov> . Access on: March 21, 2015.

EPA - United States Environmental Protection Agency. 1999. Use of monitored natural attenuation at superfund, RCRA corrective action, and Underground Storage Tank sites. Office of Solid Waste and Emergency Response, Directive 9200. 4-17 pp. Available on: <http://www. epa.gov >. Access on: September 7, 2014.

EPA - United States Environmental Protection Agency. 2014. Dense Nonaqueous Phase Liquids (DNAPLS) Overview. Available on: $<$ http://www.cluin.org/contaminantfocus/default.focus/sec/Dense_ Nonaqueous_Phase_Liquids_(DNAPLs)/cat/Overview/>. Access on: September 4, 2014.

GEOTOMO SOFTWARE. 2003. RES2DINV, version 3.53, Rapid 2D resistivity \& IP inversion using the least-square method - Geoelectrical Imaging 2-D \& 3D, Geotomo Software, Penang, Malaysia, 129 pp.

GRIFFITHS DH \& BAKER RD. 1993. Two-dimensional resistivity imaging and modeling in areas of complex geology. Journal of Applied Geophysics, 29: 211-226.

HERNÁNDEZ-SORIANO MC. 2014. Environmental risk assessment of soil contamination. InTech, New York, 905 pp.

JUHASZ AL \& NAIDU R. 2000. Bioremediation of high molecular weight polycyclic aromatic hydrocarbons: a review of the microbial degradation of benzo[a]pyrene. International Biodeterioration \& Biodegradation Journal, 45: 57-88.
KNÖDEL K, LANGE G \& VOIGT HJ. 2007. Environmental Geology: Handbook of Field Methods and Case Studies. Bundesanstalt für Geowissenschaften und Rohstoffe, Hannover Federal Institute for Geosciences and Natural Resources. Ed. Springer, 1357 pp.

KÖNIG L \& WEISS JL. 2009. Groundwater: modelling, management, and contamination. Nova Science Publishers Inc., New York, 422 pp.

LOVLEY DR. 1991. Dissimilatory Fe(III) and Mn(IV) Reduction. Microbiological Reviews: American Society for Microbiology, 55(2): 259-287.

LUDWIG R, BARCELONA M \& POINTEK K. 2000. Redox process in petroleum site characterization and remediation. Workshop on Monitoring oxidation-reduction processes for ground-water restoration. Workshop summary. Dallas, Texas, p. 25-27.

MARTINHO E, ALMEIDA F \& MATIAS MS. 2006. An experimental study of organic pollutant effects on time domain induced polarization measurements. Journal of Applied Geophysical, 60: 27-40.

MILSON J \& ERIKSEN A. 2011. Field geophysics. John Wiley \& Sons, Oxford, $297 \mathrm{pp}$.

MOREIRA CA \& BRAGA ACO. 2009. Aplicação de métodos geofísicos no monitoramento de área contaminada sob atenuação natural. Revista Engenharia Sanitária e Ambiental, 14(2): 257-264.

MOREIRA CA, DOURADO JC \& BRAGA AC0. 2006. Aplicação da técnica de caminhamento elétrico em área contaminada por derivados de petróleo. Brazilian Journal of Geophysics, 24(3): 383-392.

MOREIRA CA, LOPES SM, SCHWEIG C \& SEIXAS AR. 2012. Geoelectrical prospection of disseminated sulfide mineral occurrences in Camaquã Sedimentary Basin, Rio Grande do Sul State, Brazil. Brazilian Journal of Geophysics, 30(2): 169-179.

MUSSET AE \& KHAN MA. 2000. Looking into the Earth - An Introduction to Geological Geophysics. Cambridge University Press, 470 pp.

NAUDET V \& REVIL A. 2005. A sandbox experiment to investigate bacteria-mediated redox processes on self-potential signals. Geophysical Research Letters, 32: L11405.

SARA M. 2003. Site assessment and remediation handbook. 2nd ed., Lewis Publishers, Florida, $1161 \mathrm{pp}$.

SAUCK WA. 1998. A conceptual model for the geoelectrical response of LNAPL plumes in granular sediments. In: Proceedings of the Symposium on the Application of Geophysics to Engineering and Environmental Problems - SAGEEP'98. Chicago, IL, 805-817.

SAUCK WA. 2000. A model for the resistivity structure of LNAPL plumes and their environs in sandy sediments. Journal of Applied Geophysics, 44: $151-165$

TELFORD WMW, GEDART LP \& SHERIFF RE. 1990. Applied Geophysics. London, UK: Cambridge University Press, 2nd ed., 750 pp.

VAUDELET P, SCHMUTZ M, PESSEL M, FRANCESCHI M, GUÉRIN R, ATTEIA 0, BLONDEL A, NGOMSEU C, GALAUP S, REJIBA $F$ \& 
BÉGASSAT P. 2011. Mapping of contaminant plumes with geoelectrical methods. A case study in urban context. Journal of Applied Geophysics, 75: 738-751.

WIEDEMEIER TH, RIFAI HS, NEWELL CJ \& WILSON JT. 1999. Natural attenuation of fuels and chlorinated solvents in the subsurface. New
York: Wiley, 632 pp.

ZOGALA B, DUBIEL R, ZUBEREK WM, RUSIN-ZOGALA M \& STEININGER M. 2009. Geoelectrical investigation of oil contaminated soils in former underground fuel base: Borne Sulinowo, NW Poland. Environmental Geology Journal, 58: 1-9.

Recebido em 3 junho, 2015 / Aceito em 13 novembro, 2015

Received on June 3, 2015 / Accepted on November 13, 2015

\section{NOTES ABOUT THE AUTHORS}

Dimitri Ilich Kerbauy Veloso Geologist by Universidade Estadual Paulista - UNESP (2013). Masters student Geoscience and Environmental Science Post-graduation Program - Geoscience and Exact Science Institute - Universidade Estadual Paulista - UNESP - Rio Claro Campus. Practice areas: applied geophysics in environmental studies.

César Augusto Moreira Geologist by Universidade Estadual Paulista - UNESP (2003), Master (2005) and Doctor (2009) in Geoscience by IGCE/UNESP. Experience in Applied Geophysics, with emphasis on Electrical methods (DC Resistivity, IP, SP) and Electromagnetic methods (FEM, TEM, GPR) applied in Environmental and Mineral Prospecting studies. Assistant Doctor Professor in Applied Geology Department - Geoscience and Exact Science Institute - Universidade Estadual Paulista - UNESP Rio Claro Campus. Practice areas: applied geophysics in mineral exploration, hydrogeology, geotechnical and environmental studies.

Ariane Raissa Pinheiro Côrtes Geologist by Universidade Estadual Paulista - UNESP (2013). Masters student Geoscience and Environmental Science Postgraduation Program - Geoscience and Exact Science Institute - Universidade Estadual Paulista - UNESP - Rio Claro Campus. Practice areas: applied geophysics in mineral exploration. 